\title{
SURGICAL ENDOCRINE ABLATION FOR ADVANCED BREAST CANCER
}

\author{
By A. P. M. ForRest, B.Sc., Ch.M., F.R.C.S.Ed., F.R.C.S.Eng. \\ Lecturer in Surgery, University Department of Surgery, Western Infirmary, Glasgow
}

A suitable hormone environment contributed by the secretions of the ovaries, the adrenals and the pituitary is essential for the normal development of the female breast (Fig. I). Physiological upset of this hormonal balance, as, for instance, during pregnancy and after the menopause, leads to profound changes in the growth of the mammary glands. Abnormal breast hypertrophy may point to the presence of an endocrine-secreting tumour, while parenchymal atrophy is a constant finding in hypopituitarism (Sheehan and Summers, 1949).

Cancer of the female breast is similarly influenced by the endocrine status of its host, as is evidenced by the exacerbation of pain of osseous metastases during the premenstrual period (Kennedy, 1956) or rapid course of the disease when complicated by pregnancy. Depression of hormone production at the menopause probably contributes to the relative decrease in the incidence of breast cancer at this age (McKenzie, 1955) and is believed to account for the remissions in the course of the disease which may occur at that time of life. The incidence of breast cancer in patients castrated in their youth is unfortunately not known, although in patients with established cancer of the breast the incidence of previous oophorectomy is one-tenth that found in a hospital population (Hewell, r937). Archer (1953) traced from the world literature nine females with co-existing Simmond's disease and malignancy. None had cancer of the breast, which, in view of the high incidence of breast as a site of malignancy in women, is unexpected. Cases are on record (Cade, 1954) in which regression of breast cancer has occurred following metastatic invasion of the adrenals and ovaries.

In recent years upset of the hormonal balance by surgical or pharmacological means has become established as a palliative measure in patients with widespread or recurrent mammary cancer. This form of therapy is not indicated in the early case, where surgery and radiotherapy are still the treatments of choice. However, when the cancer, by local or general spread, has advanced beyond the boundaries of operability, or where recurrence has followed orthodox surgical treatment, endocrine

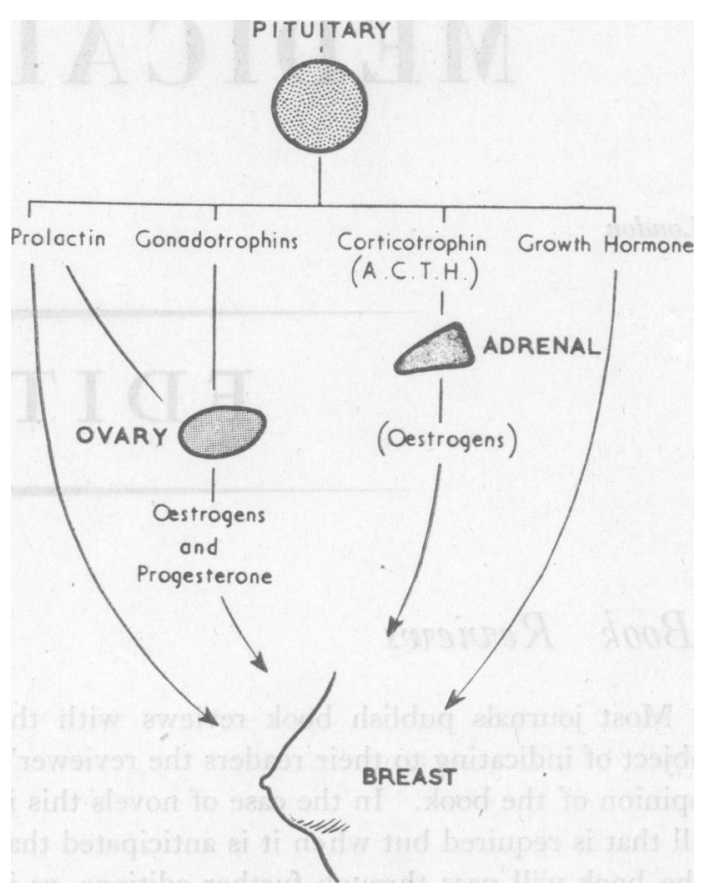

Fig. 1.-Hormones and breast development.

ablative therapy has offered worth-while palliation and a new hope for the future control of the disease.

\section{Oophorectomy}

The recent revival of surgical castration in the treatment of advanced cancer of the breast has fully confirmed the original observations of Sir George Beatson (1896); in a recent report from the Memorial Centre, New York, 43.7 per cent. of I9I premenopausal women with inoperable or recurrent breast cancer had objective remissions following this operation (Treves, 1956). In other reports the remission rate varies from 15 to 50 per cent. In women past the menopause oophorectomy by itself is of little value. The length of remission after surgical castration tends to be short (the 


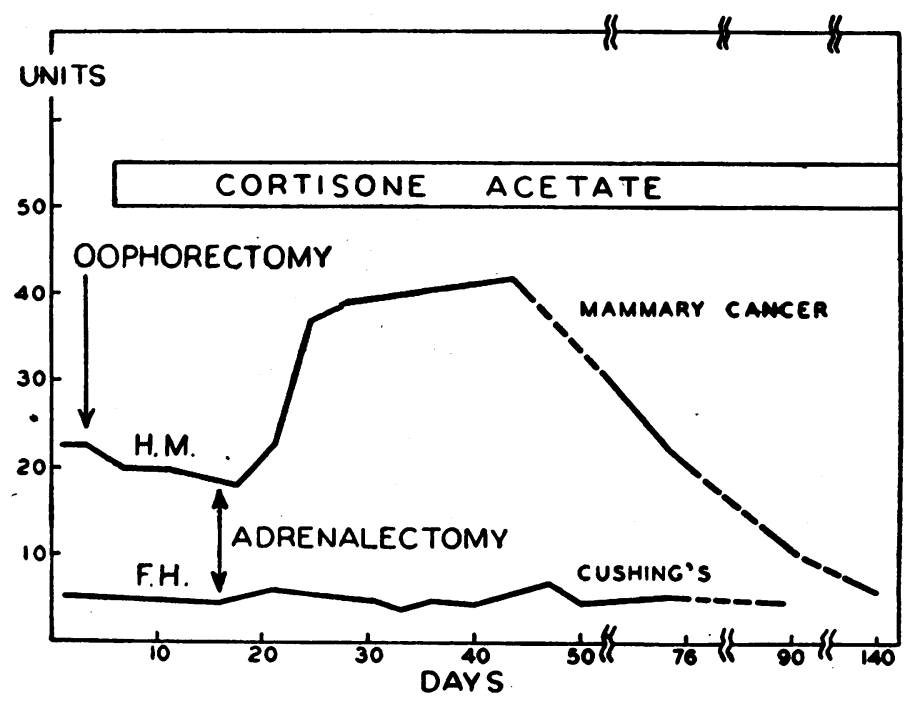

Fig. 2.-Serum alkaline phosphatase of woman aged 39 years with mammary cancer and bone metastases. Response to oophorectomy and adrenalectomy. (Upper graph.) From Huggins and Dao (F.A.M.A., 1953, 15!, 1388 ).

average length of remission in 75 patients reported by Pearson et al. (1955a) was nine months), but approximately half of those patients who respond to oophorectomy may expect to have further improvement when the adrenals are removed (Pearson et $a l .$, I955a and b).

Suppression of ovarian function by irradiation has also been widely used and in most instances a dose of $\mathrm{I}, 200 \mathrm{r}$ will accomplish castration in six to eight weeks. However, its effect may be only temporary (Nathanson et al., 1940) and X-ray castration should be reserved for those patients who are unfit for the more certain surgical technique.

\section{Adrenalectomy}

Until the advent of cortisone total adrenalectomy, although attempted in four patients with prostatic cancer (Huggins and Scott, 1945), proved lethal, while the results of subtotal removal of the adrenal glands in metastatic breast cancer did not justify further trial (Atkins et al., 1957). However, with the availability of cortisone for maintenance therapy, adrenalectomy became a safe procedure, and by 1953 Huggins had reported the results of this operation in 53 women with advanced mammary cancer (Huggins and Dao, 1953). West and his colleagues (1952) first demonstrated that removal of the adrenal glands in women who had previously been oophorectomized could effect further improvement in their metastatic cancer. The many reports which have since become available suggest that this operation, usually combined with oophorectomy, will induce objective remission in about one-third of patients with late mammary cancer (Kennedy, 1956, 34 per cent. of 400 cases reviewed). The average duration of remission in 26 responding patients described by Pearson (1956) was $278+$ days. In our own experience in the Professorial Unit at the Western Infirmary, Glasgow, eight of 24 patients with advanced breast cancer have had worth-while palliation following adrenalectomy and oophorectomy.

In premenopausal women with breast cancer failure to respond to oophorectomy usually indicates that adrenalectomy will meet with a similar lack of response (Pearson, et al., 1955a and b). However, worth-while response to adrenalectomy, despite a negative response to castration, has been claimed by Dao and Huggins (1955) and Perlia et al. (1956). The sole criterion of response in Huggins's case (Huggins and Dao, 1953) was the alkaline phosphatase level in the serum (Fig. 2). Perlia et al. do not record the method of castrating their patient and it seems probable from their previous report that this was by irradiation (Taylor et al., 1953).

It appears likely that adrenalectomy and oophorectomy influence the growth of breast cancer by similar mechanisms and functioning ovaries should be removed before resorting to the more radical operation. Adrenalectomy and oophorectomy as a primary procedure should be reserved for women who are more than five years past the menopause and in whom ovarian function has ceased. 


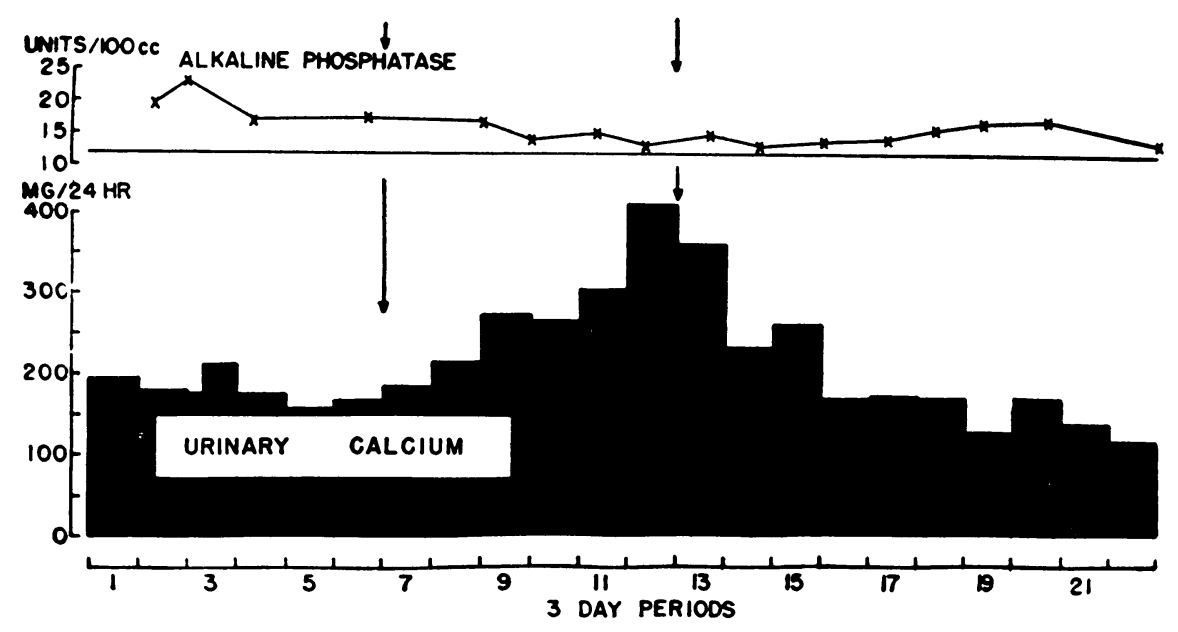

Nitrogen, phosphorus, and calcium balance during growth hormone administration to a woman with meta.
slatic mammary cancer, who had had oophorectomy, adrenalectomy, and hypophysectomy. Dietary intake is ploticd downward from the zero line. Fecal and urinary output are plotted from the dietary intake line.

FIG. 3.-Urinary excretion of calcium in a woman with metastatic cancer of the breast, who was in remission following oophorectomy, adrenalectomy and hypophysectomy. Response to bovine growth hormone. (Administered between arrows.) From Pearson et al. (F.A.M.A., I956, г6r, г 7).

\section{Accessory Adrenal Tissue}

The belief that adrenalectomy and oophorectomy abolishes oestrogen excretion (Huggins and Dao, I955) has not been supported by others using improved methods of assay (Strong et al., 1956; Bulbrook and Greenwood, I957), while recoverable quantities of pregnanediol have also been found in the urine of adrenalectomized and oophorectomized women (Strong et al., 1956). Despite the failure of infusions of ACTH to increase the excretion of these compounds, they may originate from accessory adrenocortical tissue, already maximally stimulated by the endogenous ACTH of the patient. In man accessory adrenocortical tissue is more common than was previously believed and adrenal rests were found in the coeliac area in 32 of roo consecutive autopsies (Graham, 1953) and in the infundibulopelvic ligament in seven of 30 consecutive gynaecological operations (Falls, I955). Huggins found accessory adrenals along the inferior vena cava at adrenalectomy in three of his 175 patients (Huggins and Dao, 1955). It is firmly established that hypertrophied accessory adrenocortical tissue will maintain one in five totally adrenalectomized rats in good health (Jaffe, I926) and three cases have been recorded in which adrenal rests allowed survival despite total destruction of the adrenals in man (Karakascheff, 1906; Roth, I 889). It is tempting to believe that functioning accessory adrenal tissue may account for certain of the later relapses in women with breast cancer who initially responded to adrenalectomy and that the subsequent regression with hypophysectomy reported in six cases (Pearson et al., 1956-five cases; Luft, 1957-one case) was due to removal of the source of endogenous AC'TH.

\section{Hypophysectomy}

Surgical hypophysectomy in the treatment of advanced breast cancer was first performed by Olivecrona in Stockholm (Luft and Olivecrona, 1953), and in a recent report of $5^{2}$ cases Luft and his colleagues (1956) describe objective remissions (including six arrests) in 22 of the $4 \mathrm{I}$ patients evaluated. In March 1956 Bronson Ray reported his experiences of 123 hypophysectomies for this disease and in a recent evaluation of 74 of these patients treated between March 1954 and January 1956 Pearson (I956) recorded objective remissions in 36 (including eight arrests). Other reports of smaller numbers of cases (Kennedy, 1956; Matson, I956; Connolly, 1957; Radley Smith, I957) give comparable results.

It appears that surgical hypophysectomy will give at least as good results as adrenalectomy and oophorectomy in the treatment of breast cancer. As a result of a controlled trial of the two procedures in a group of 60 women, Atkins and his colleagues believe hypophysectomy to be superior (Atkins et al., 1957). However, four premenopausal women who failed to respond to oophorectomy also failed to respond to hypophysectomy (Pearson et al., 1956), while none of nine cases who failed to respond to adrenalectomy and oophorectomy had any improvement when hypophysectomy was subsequently carried out (Pearson, r956- 
one case; Luft, 1957-four cases; personal datafour cases). The only strong evidence that the pituitary may influence breast cancer growth directly rather than through other endocrine glands was the stimulation of the excretion of urinary calcium in an oophorectomized, adrenalectomized and hypophysectomized patient with breast cancer and osseous metastases by a pure preparation of beef growth hormone (Pearson et al., 1954, 1956) (Fig. 3).

Even in trained hands surgical hypophysectomy has a considerable morbidity and may lead to visual defects, anosmia, rhinorrhoea, meningitis and neurological complications. Furthermore, complete removal of the hypophysis is not an easy surgical task and will be accomplished consistently only after considerable experience of the technique. Recently other methods of achieving pituitary ablation have been under consideration.

\section{Pituitary Stalk Section}

Destruction of the pituitary stalk in man results in considerable necrosis of the anterior lobe (Russell, 1956) and stalk section has been practised as a simpler alternative to excision of the pituitary (Northfield, 1957). However, although the immediate clinical results are similar to those after surgical hypophysectomy, the extent of necrosis caused by this procedure is disappointing.

\section{Coagulation Hypophysectomy}

Diathermy coagulation of the normal hypophysis in Cushing's disease results in only partial destruction of the gland (Luft et al., 1952) and this method is not applicable when complete destruction is desired. Bauer (1956) treated four cases of advanced breast cancer by coagulating the pituitary by an electrode inserted into the sella turcica by a paranasal transethmoid route. Insufficient necrosis was discovered at post-mortem (Bauer et al., 1956). Our own experience with a high-frequency current passed between two electrodes inserted by the transnasal route was not encouraging (Fig. 4).

\section{Radiation Hypophysectomy}

Unsatisfactory results followed irradiation of the pituitary by standard X-ray equipment in cases of Cushing's disease (Bishop et al., 1954), while the delivery of $\mathrm{X}$-rays to give up to $10,049 \mathrm{r}$ to the normal pituitary in cases of breast cancer caused neither clinical improvement, hypopituitarism nor histological change (Kelly et al., 1951). The use of the $23 \mathrm{meV}$ Betatron has not produced selective necrosis of the pituitary in the experimental animal (Arnold, 1954) or in man (Nickson, 1956). On the other hand, the pencil-like proton beam from the r84-in. Cyclotron used by Lawrence and Tobias (1956) allows focal irradiation to be de- livered at some distance from the surface of the body, and by this method Lawrence et al. (1956) have delivered 13,000 to $32,000 \mathrm{r}$ to the pituitary in 26 patients with advanced breast cancer. The results of this method of treatment cannot yet be assessed.

Internal. In 1938 Fattison and Swan treated two patients with Cushing's disease by the implantation of radon seeds into the pituitary gland at craniotomy, but the results of a further trial of their method (Northfield, I949) were unsatisfactory. Doses of up to $9 \mathrm{mc}$ failed to destroy the pituitary completely. Rasmussen and his colleagues (1953) suggested that the isotope of yttrium, yttrium ${ }^{90}$, might prove a suitable agent to accomplish com-

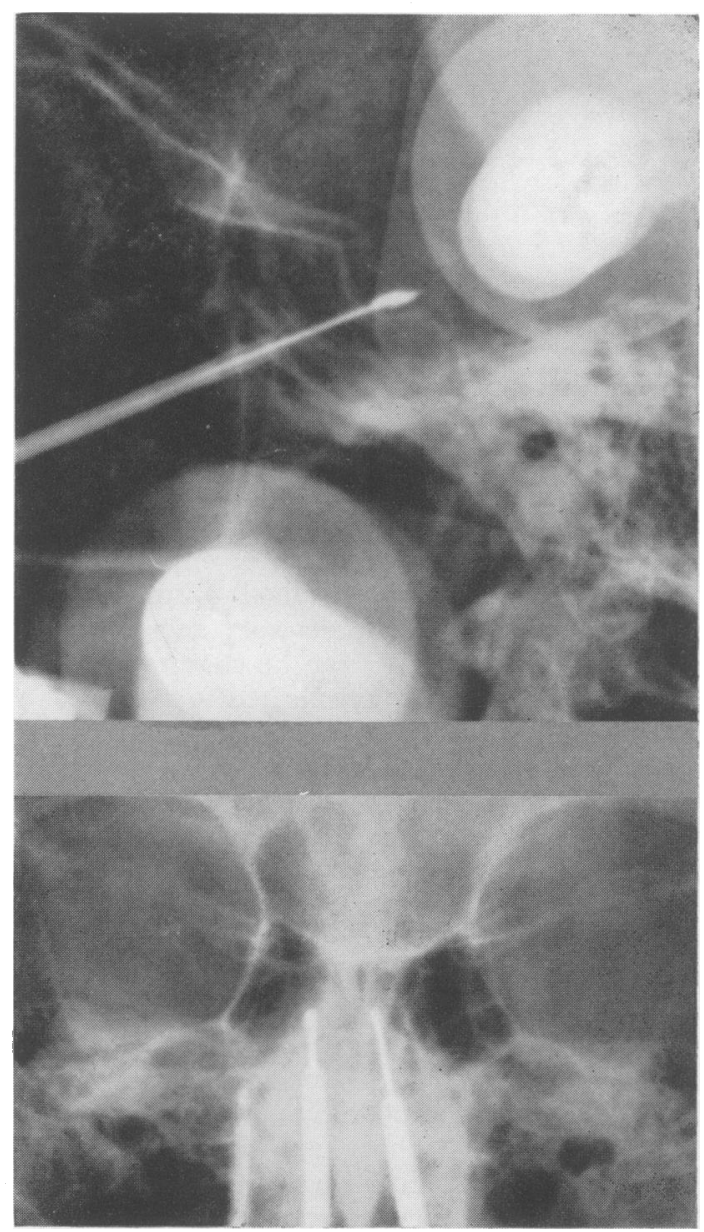

Fig. 4.-Attempted destruction of pituitary by high frequency current.

(a) Lateral and anteroposterior radiographs showing electrodes introduced into pituitary fossa. 


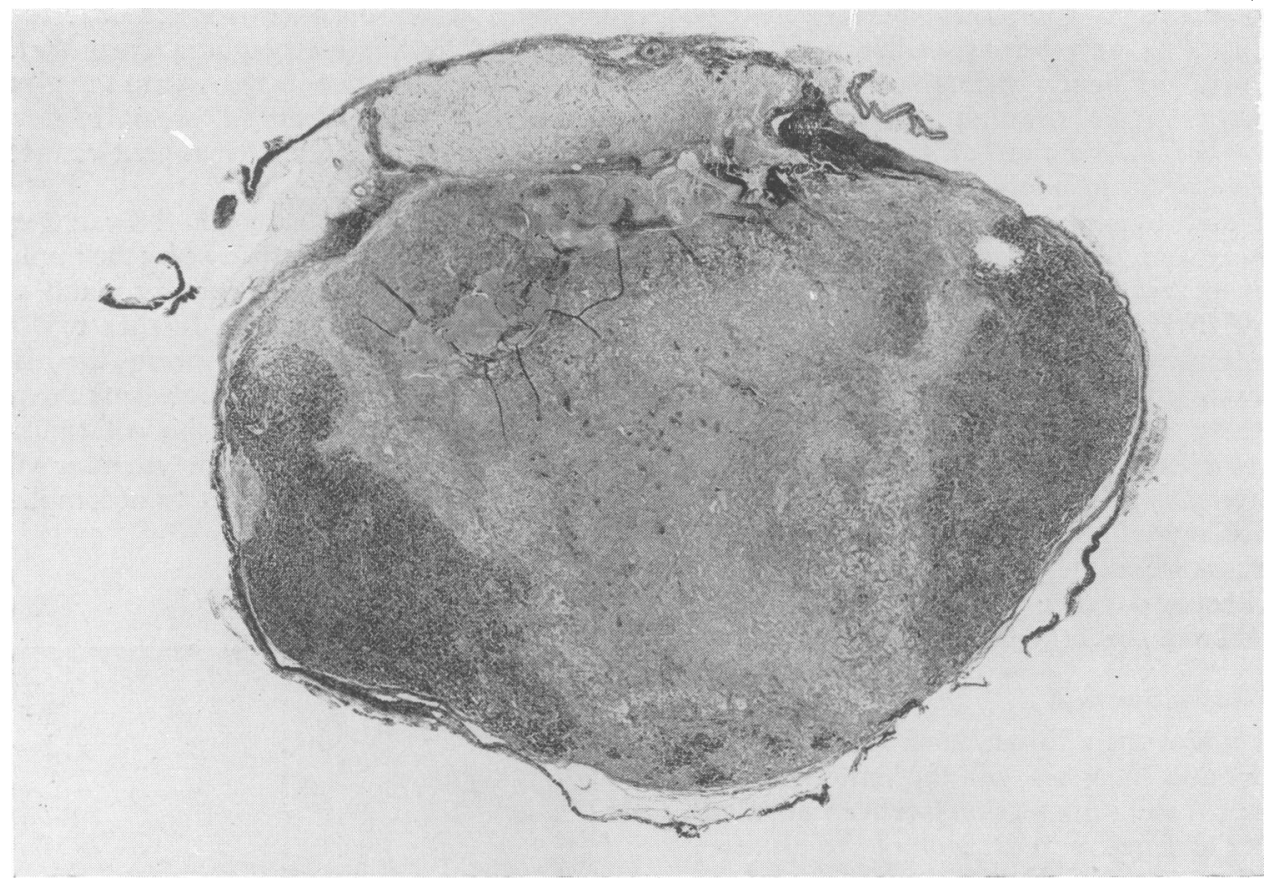

Fig. $4(b)$.- Photomicrograph of pituitary two weeks after treatment showing extent of destruction.

plete pituitary destruction when introduced into the gland at craniotomy and confirmed this in the monkey. This isotope has a short half-life of 64 hours and its property of emitting only beta radiations of high energy $(2.2 \mathrm{meV})$ which have a maximum penetration in tissue of approximately I cm. makes it suitable for effecting limited local necrosis (Fig. 5). The target substance, yttrium oxide, is a powder which can be compressed into beads or rods, which, when heated to $1,700^{\circ} \mathrm{C}$. in an induction furnace, fuse into a ceramic mass which is suitable for activation in the atomic pile. Encouraged by their results in the monkey, these workers have treated 19 patients with advanced breast cancer by the implantation of yttrium beads into the pituitary gland at craniotomy (Yuhl et al., I955; Evans, 1956). Five cases have had regression of disease, but in none has complete destruction of the pituitary been found at autopsy.

In an endeavour to diffuse radioactive material throughout the gland, Rothenberg et al. (1955) injected 2 c.c. of a solution containing $10 \mathrm{mc}$ radioactive chromic phosphate into the pituitary fossa at craniotomy in six patients without complication, and in this country a similar technique has been used by Davies (I956). In other hands this technique has not been free from neurological complications (Eliel, 1956).

Radley Smith (1957) combines surgical and

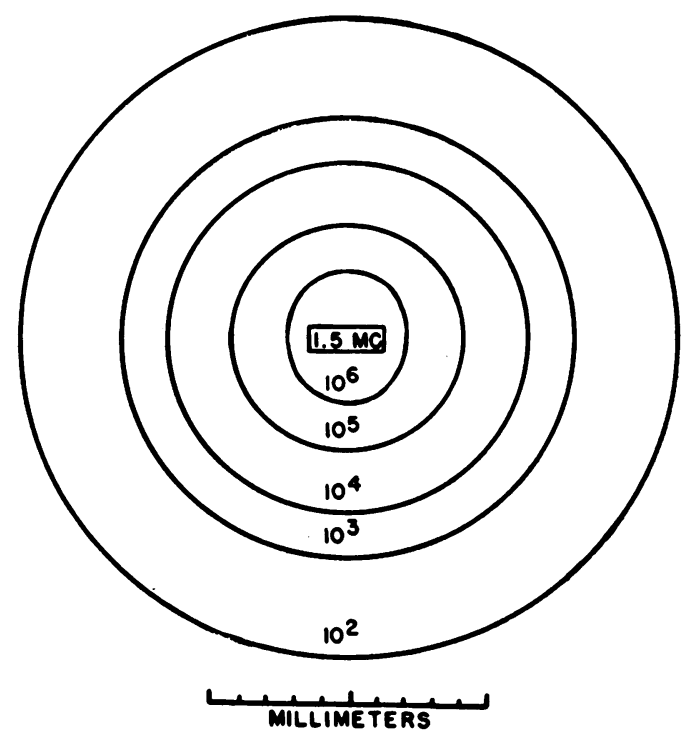

Fig. 5.-Isodose curves indicating total tissue dose in rep surrounding a 1.5 mc pellet of yttrium ${ }^{90}$. Note rapid fall-off of activity in tissue. From Yuhl et al., Surgical Forum (1955).

irradiation methods by packing the sella turcica with fibrin foam containing $7.5 \mathrm{mc}$ radioactive gold after surgical removal of the gland. 
Table I.-Pituitary Radon IMPlant fOR Advanced Breast Cancer

January, 1955 to February, 1956, 36 cases, assessed February 28, 1957

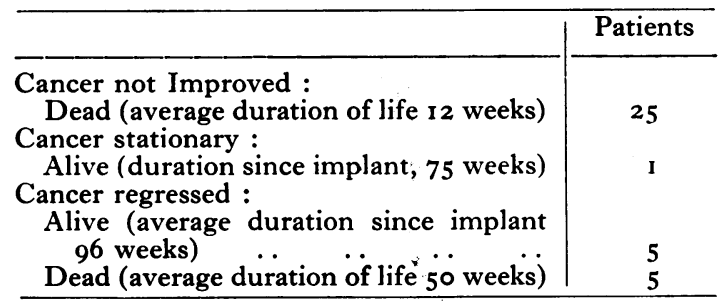

In 1955 we reported a method of introducing radioactive material into the pituitary fossa by means of a cannula introduced under X-ray control through the nose and sphenoidal sinus (Forrest and Peebles Brown, 1955). During 1955, 36 patients with advanced breast cancer and nine patients with other malignancy were treated by the implantation of 2-4 $5 \mathrm{mc}$ radon seeds into the sella turcica (Forrest et al., 1956) with the hope of selectively destroying the pituitary gland without the need for craniotomy. Unfortunately, the penetrating gamma radiations of the radon damaged also the hypothalamus and optic chiasma, causing serious loss of vision in seven of the 45 patients, a high incidence of permanent and severe diabetes insipidus and radiation changes in the hypothalamus at autopsy. Despite these grave disadvantages, a good remission of disease followed this relatively simple method of treatment in 10 of the 36 patients, five of whom are still alive and in remission in an average time of 96 weeks after implantation (Table I). Complete destruction of the pituitary was not found in any of the cases examined post-mortem, but clinical and biochemical evidence of hypopituitarism suggested that depression of function had extended beyond the boundaries of complete necrosis.

It was concluded that gamma radiations from internal sources were not sufficiently selective to achieve safe pituitary destruction, a conclusion also reached by other workers with radon (Cade, 1955) and with radioactive gold (Greening, I956, 1957). The experimental work with the isotope yttrium $^{90}$ and its safe introduction into the human pituitary at craniotomy (vide supra) suggested that it might prove suitable for insertion by our technique. For this purpose we have used cylindrical rods of sintered yttrium oxide of $6 \times 2 \mathrm{~mm}$. in size and $50 \mathrm{mg}$. weight, which are activated in the atomic pile to 5-6 mc. To obtain a good distribution of dose we have modified our director apparatus to allow the simultaneous insertion of two cannulae into the pituitary fossa, one through either nostril, frequent X-ray checks controlling

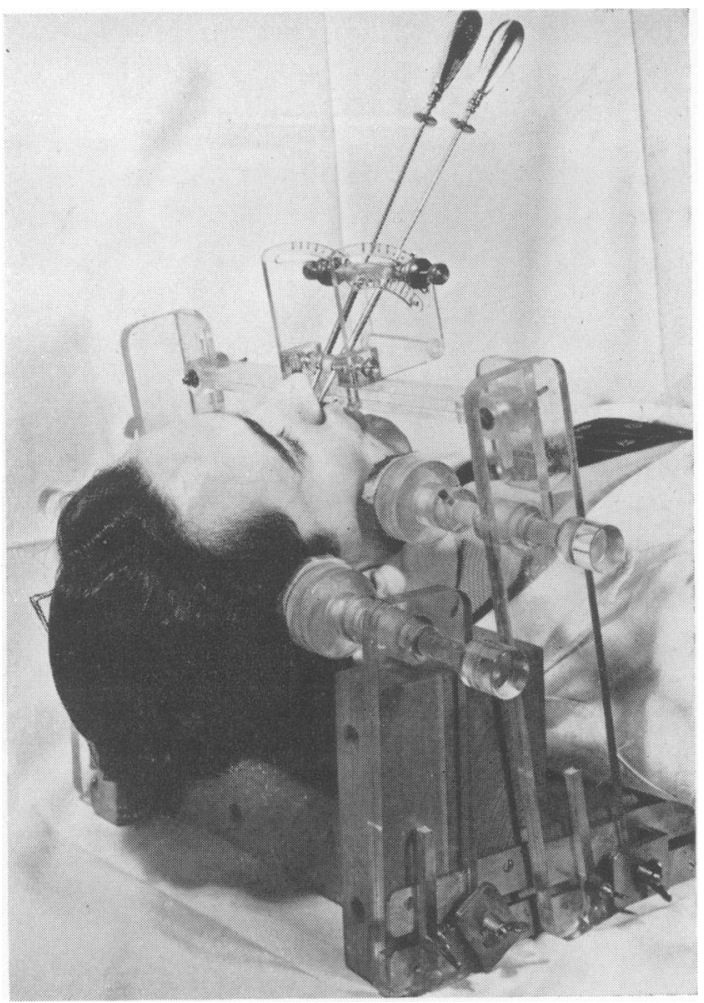

FIG. 6.-Director apparatus used for yttrium ${ }^{90}$ implantation of the pituitary.

(a) Director apparatus.

the direction of the advancing cannulae (Fig. 6). The rods are introduced, one through each cannula, so that they lie symmetrically one on either side of the midline. Care is taken to place the rods in the lower half of the pituitary fossa at a safe distance from the hypothalamus and optic chiasma (Fig. 7).

Since March 1956 we have treated 37 patients with advanced mammary cancer by the implantation of 8-14 mc yttrium ${ }^{90}$ into the pituitary fossa. All patients have been in an advanced stage of their disease, with extensive local recurrence or widespread metastases, and were treated in this way only when other forms of therapy offered no hope of palliation.

One patient died during implantation from respiratory failure due to pulmonary metastases. Defects of visual fields were discovered in four patients, but these were of minor significance and did not progress (Fig. 8). One patient with a visual defect is alive and in remission 12 months after implantation without increase in the initial visual loss. While temporary polyuria is usual during the first few weeks after implantation, permanent 


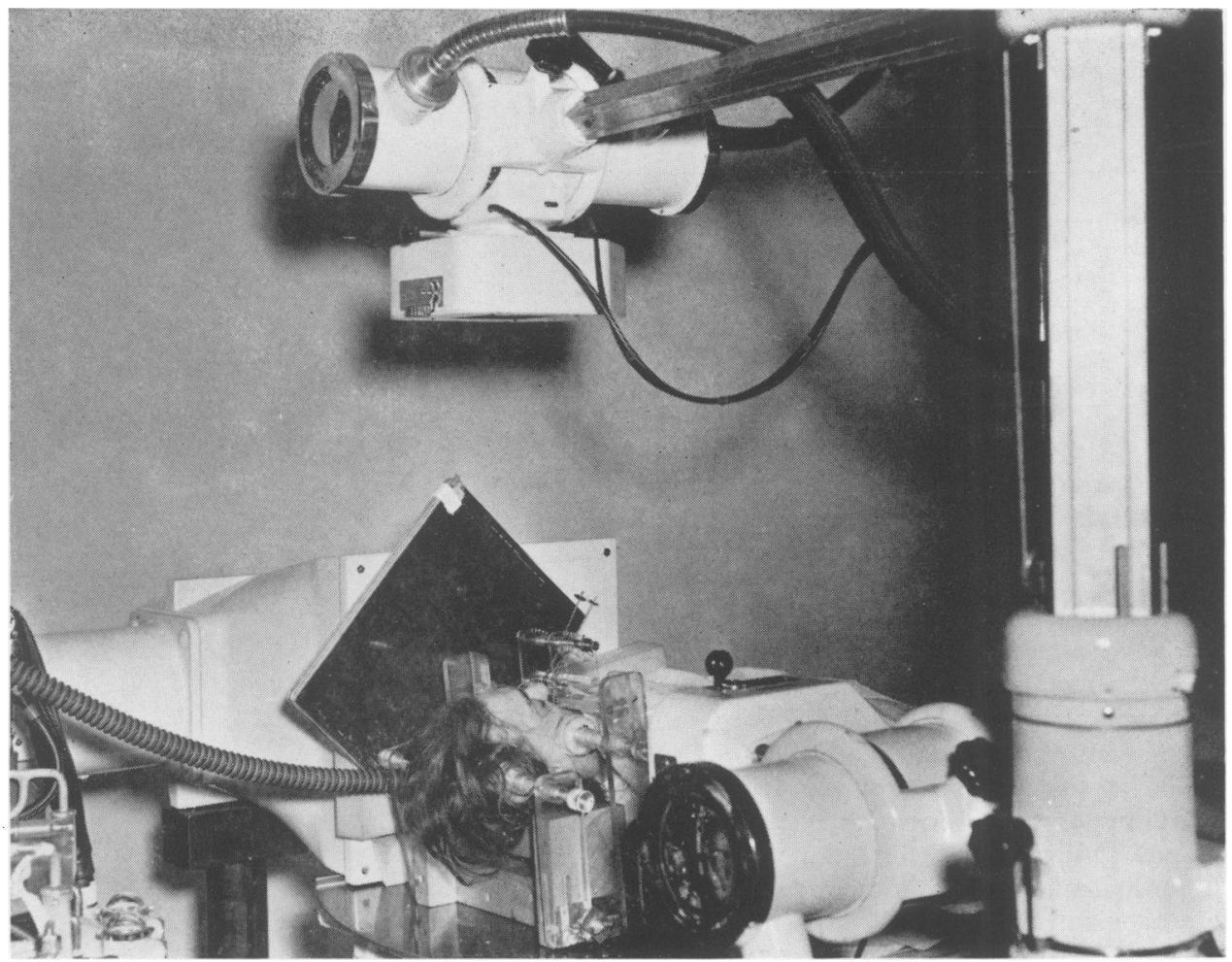

FIG. $6(b)$.- Implantation in progress-to show method of taking serial radiographs. (The director apparatus was constructed by Mr. Angus MacDonald in the Western Infirmary workshop.)

diabetes insipidus has occurred in only two patients (Fig. 9). In one of these patients (N. N.), who also had a visual defect, a voracious appetite and altered sleep rhythm suggested damage to other hypothalamic centres. In four patients profuse rhinorrhoea commenced four to 27 days after implantation. Meningitis, controlled by intrathecal penicillin, developed in two. Three patients were treated by muscle graft at craniotomy (Mr. J. Sloan Robertson), while in the fourth rhinorrhoea spontaneously ceased. A finding believed to have contributed to the development of rhinorrhoea was a fracture of the sella turcica, probably caused by the forceful insertion of the trocar and cannula in two planes. To prevent this we now use a diamond steel cutter to drill a clean hole in the bone.

To assess the value of yttrium ${ }^{90}$ implantation in the treatment of advanced breast cancer, we have undertaken a controlled trial in which patients considered fit for either procedure are selected by random methods for adrenalectomy or pituitary implantation. Nineteen patients treated by pituitary implantation are included in this series (Table 2). Five of these have shown objective improve-
TABl.E 2.-Pituitary YTtRium ${ }^{90}$ Impl.ANT For Advanced Breast Cancer

March, 1956 to March, 1957,37 cases

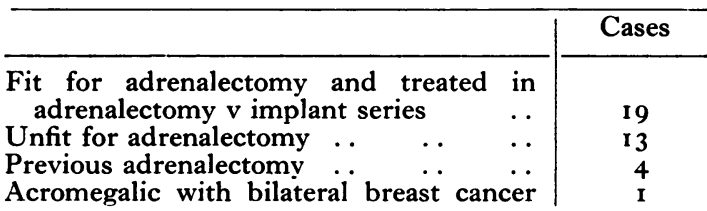

ment in their disease, while four are not yet evaluated. Thirteen patients were considered unfit for adrenalectomy and therefore excluded from the trial. They were treated by yttrium ${ }^{90}$ implant, but only two have had benefit. Implantation failed to influence the course of the disease in four patients who had previously failed to respond to adrenalectomy and oophorectomy. In the remaining patient, an acromegalic with bilateral breast cancer, the tumours do not appear to have progressed since the introduction of $18 \mathrm{mc}$ yttrium $^{90}$ in four rods into her large pituitary fossa (Table 2) (Fig. IO).

Complete destruction of all pituitary tissue has been found in two of the seven cases which have 


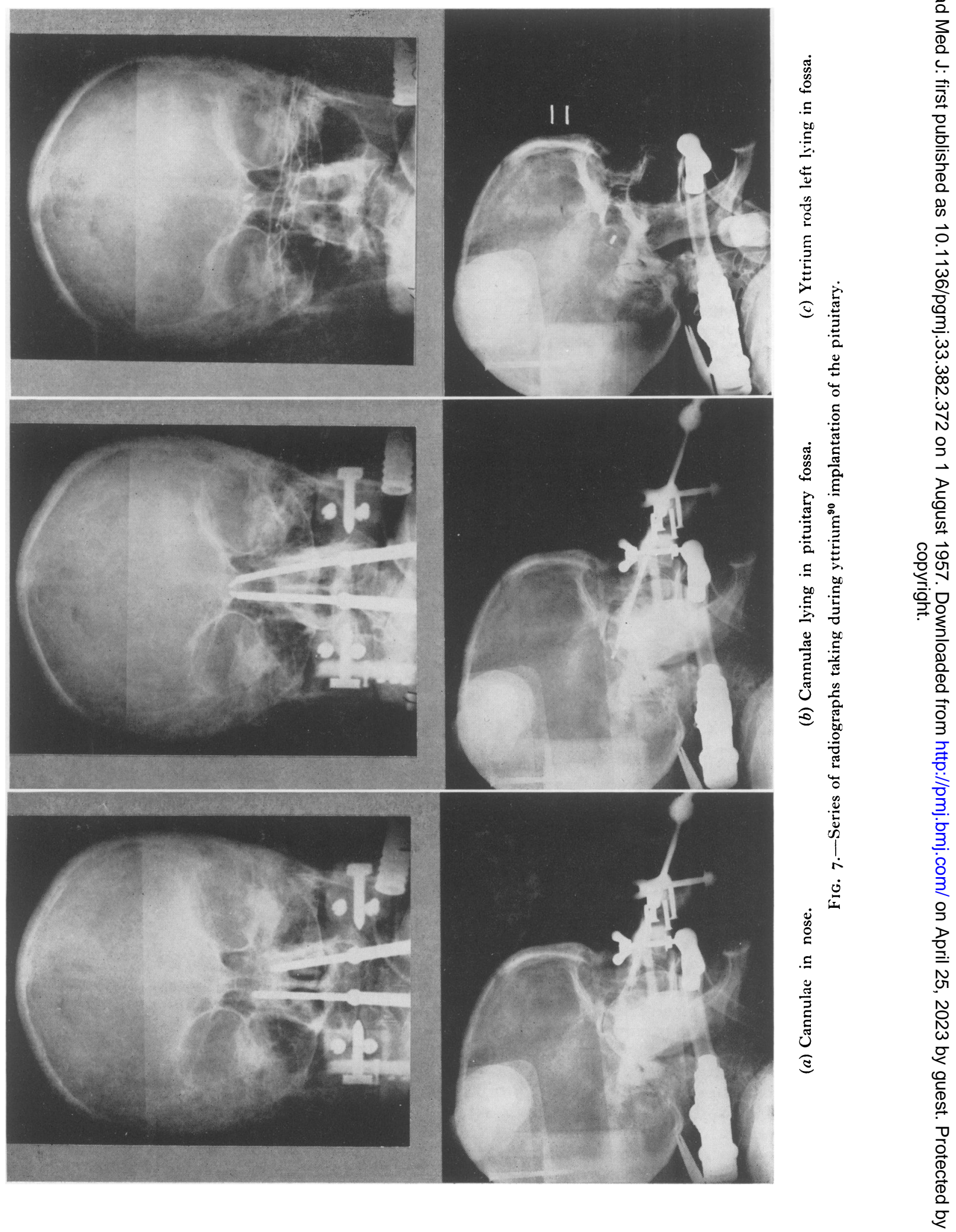


VISUAL DAMAGE FOLLOWING PITUITARY IMPLANT

90 YTTRIUM - MAR. '56-FEB. 57
TOTAL NO OF CASES - 34
NO WITH VISUAL DEFECT -4
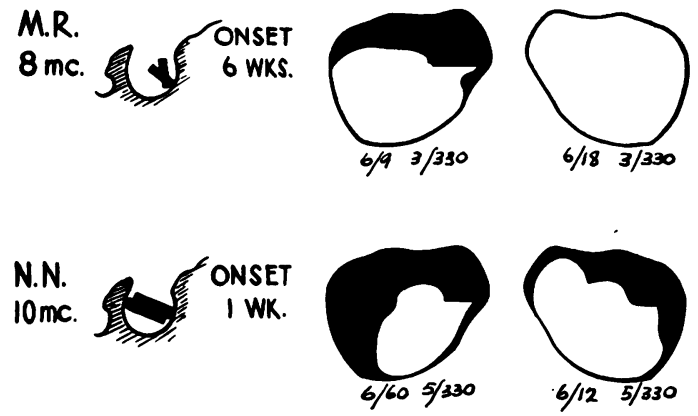

M.B.
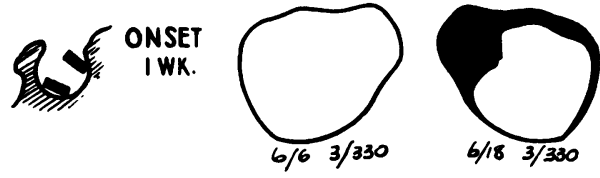

McV.
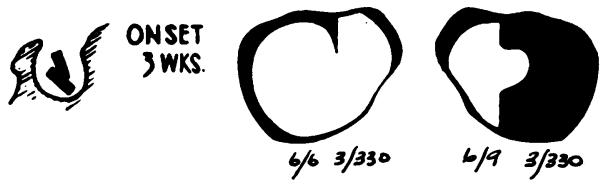

FIG. 8.-Visual damage in four patients following pituitary implantation with yttrium ${ }^{90}$. Note high position of radioactive source.

been examined post-mortem. In a third case only a few cells remained at one corner of the gland, while the estimated extent of destruction in the remainder was 90 to 95 per cent. of the gland mass (Fig. II).

Accurate assessment of the extent of destruction by clinical and biochemical means is difficult, but our findings would suggest that initial benefit may occur despite incomplete destruction of the gland, a conclusion which has been reached by others (Greening, 1957; Northfield, I957). However, one would expect that under these circumstances regeneration of the gland remnants would lead to recrudescence of tumour growth. Permanent suppression of gland function by complete destruction should therefore be our aim.

Other workers use smaller sources of yttrium ${ }^{90}$ and Greening (I957) introduces two rods $I .3 \times$ $4 \mathrm{~mm}$. in size (each of $3 \mathrm{mc}$ ), one into each half of the pituitary fossa, using the image intensifier for radiological control. A similar method is used by

\section{PITUITARY YTTRIUM 90 IMPLANT}

TREATED TO FEBRUARY $1957-34$ PATIENTS SEVERE PERMANENT DIABETES INSIPIOUS - 2 PATIENTS

N.N. $10 \mathrm{mC}$
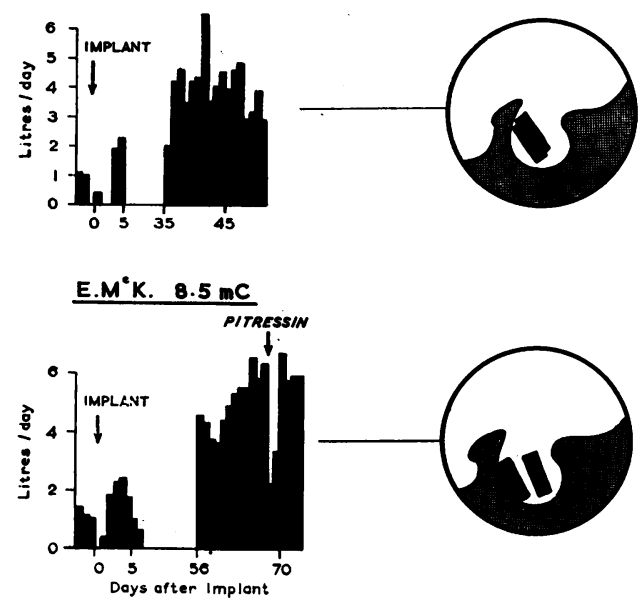

FIG. 9.-Diabetes insipidus following yttrium ${ }^{90}$ implantation of the pituitary in two patients.

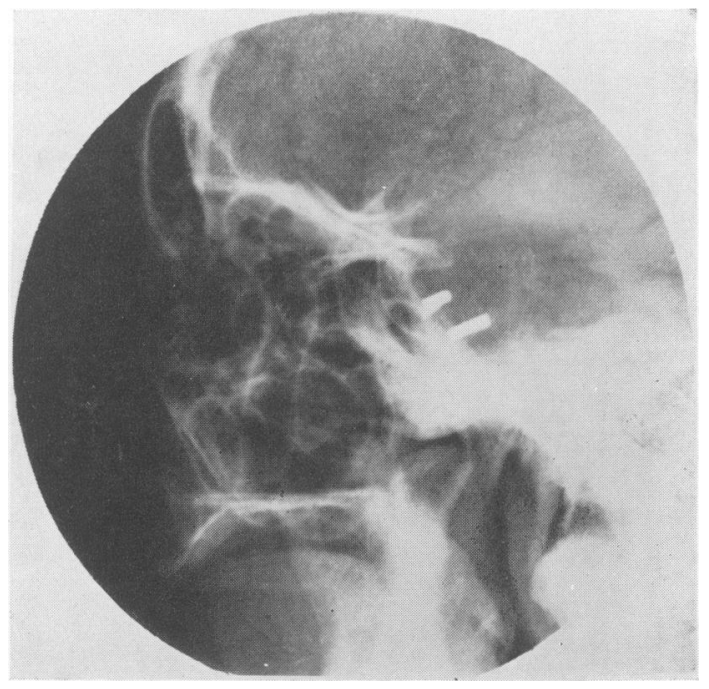

FIG. 10.-Lateral radiograph of pituitary fossa of acromegalic with breast cancer. Four yttrium ${ }^{90}$ rods in position (total dose $18 \mathrm{mc}$ ).

Fergusson (1956), while Mallard et al. (1956) advocate the distribution of six I $\times 3 \mathrm{~mm}$. rods of total activity $9 \mathrm{mc}$ throughout the gland. Notter (1957) has perfected a technique in the cadaver in which he introduces 40 small spherical sources which take up the shape of the pituitary gland (Fig. 12). 


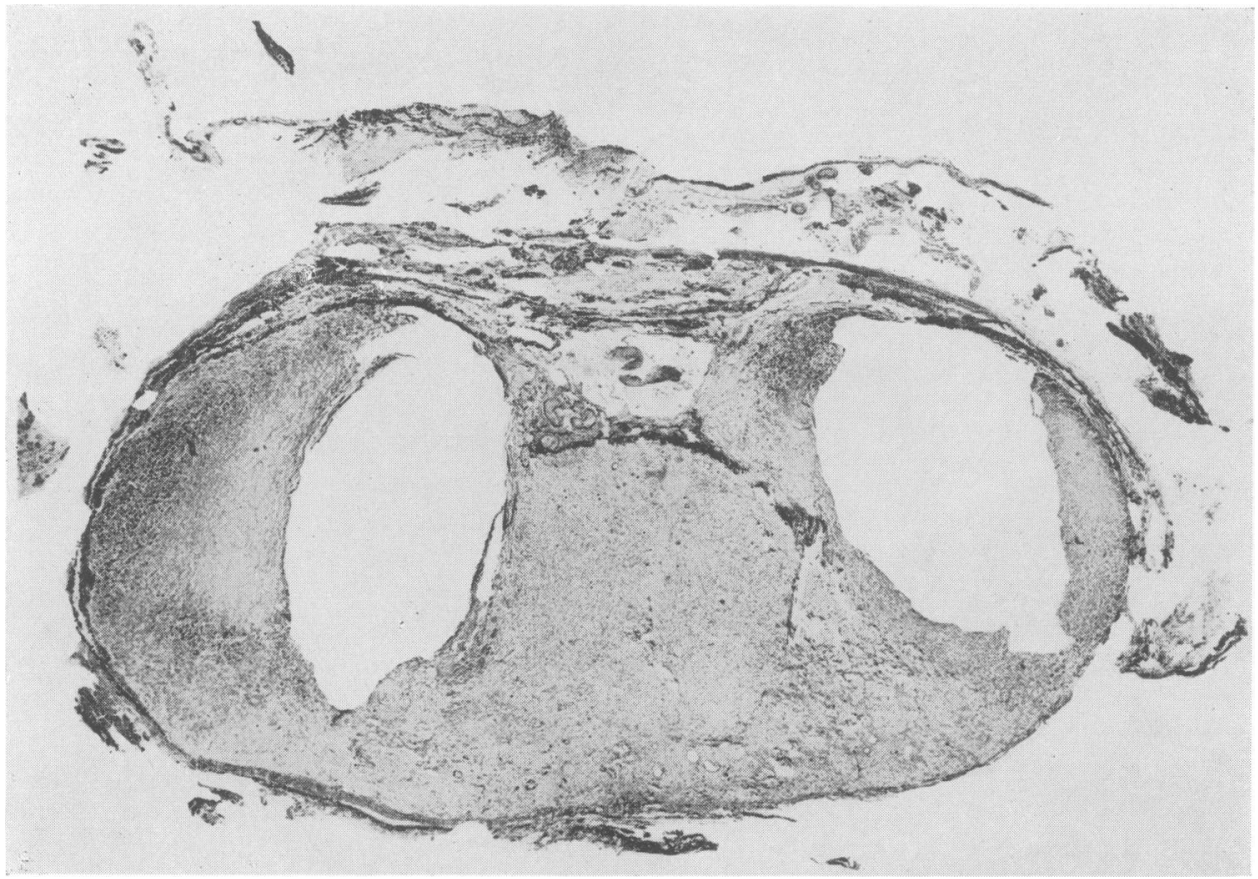

FIG. II.-Photomicrograph of pituitary four and a half weeks after implantation of II.3 mc. yttrium ${ }^{90}$ showing total destruction of gland.

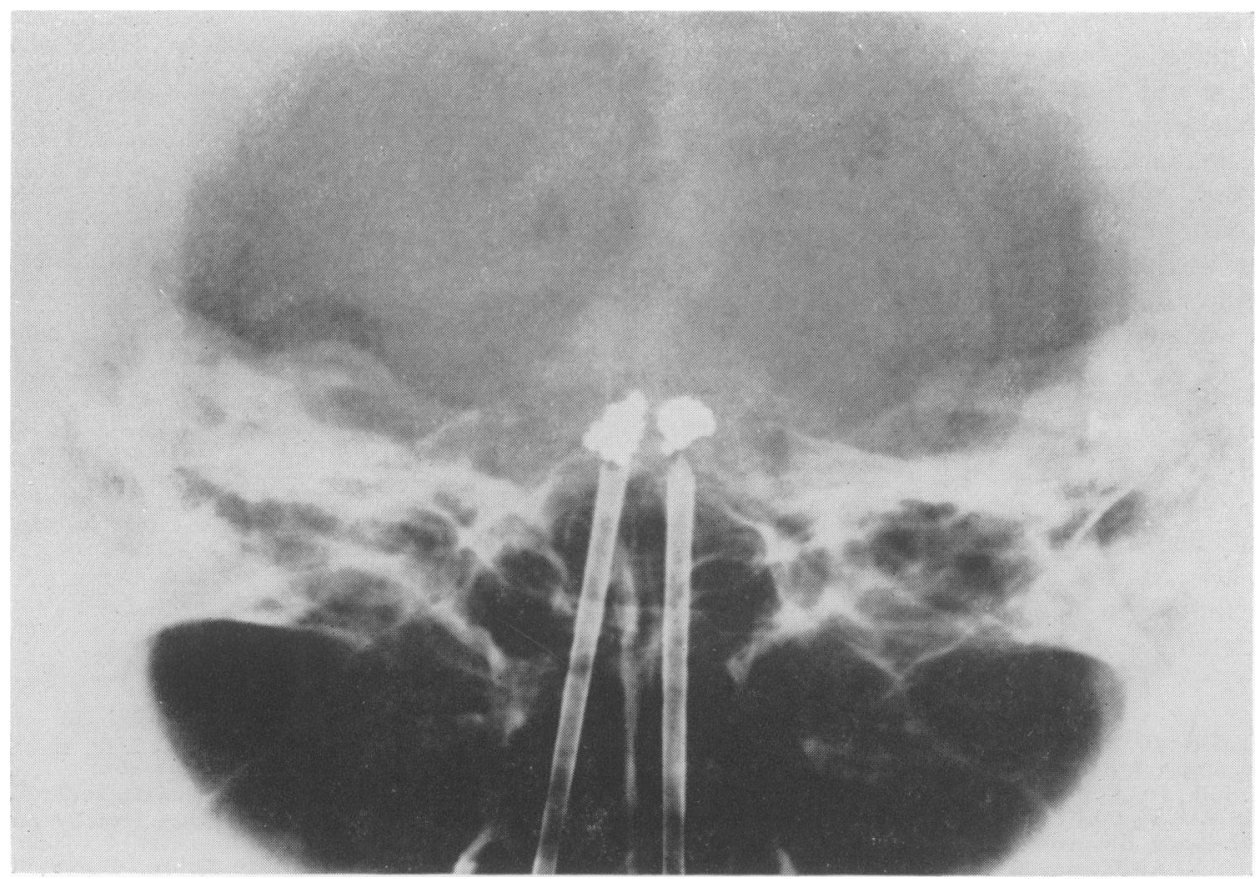

FIG. 12.-Method of implantation using small sources devised by Dr. Gustav Notter, Stockholm (1957). (a) Anteroposterior radiograph of cadaver after implantation. 


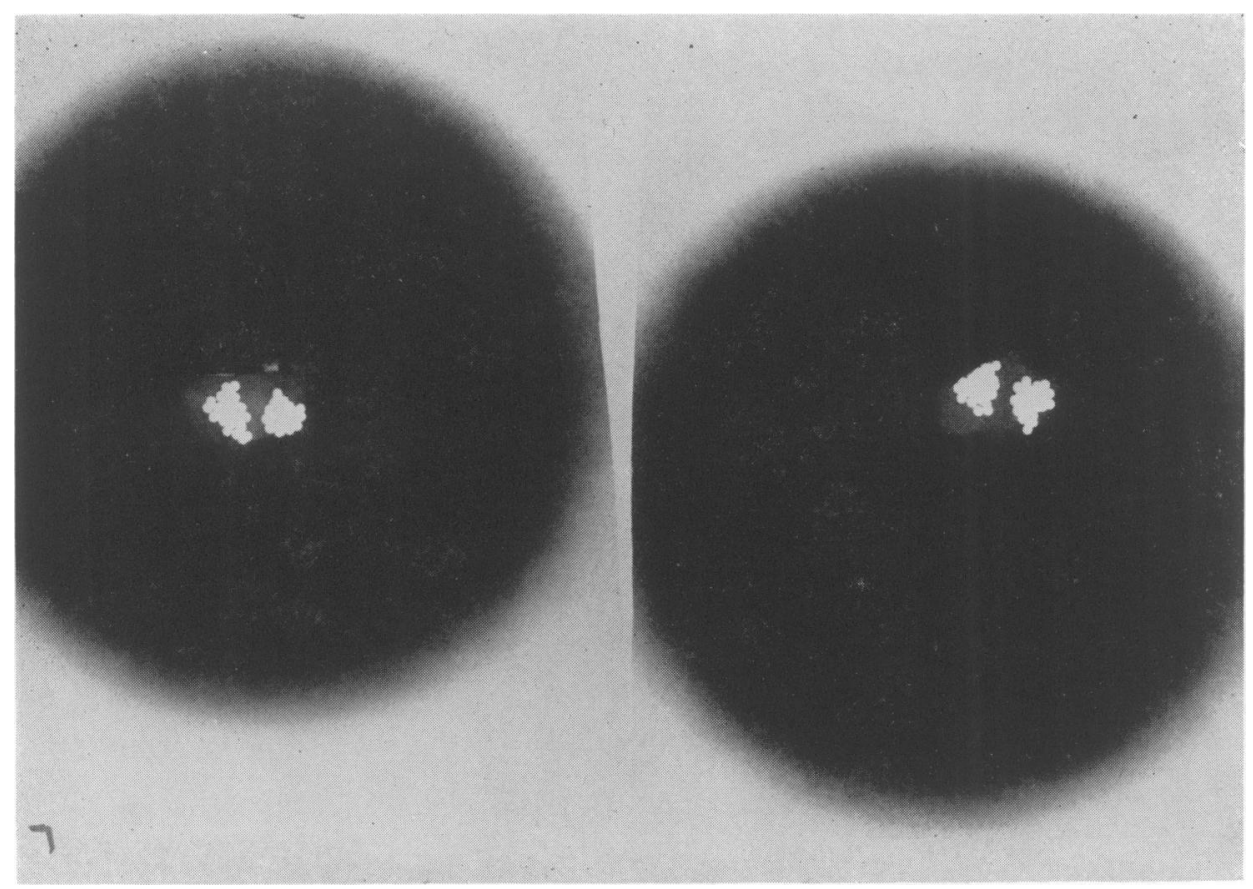

FIG. $12(b)$.- Radiographs of excised pituitary.

\section{Conclusions}

It is clear that methods of destroying the pituitary other than by surgery are still at an experimental stage and that they have no place in the routine management of advanced cancer of the breast, except in the debilitated patient unable to stand surgery. While surgical hypophysectomy, in skilled hands, has proved a satisfactory palliative procedure, oophorectomy, either alone or with adrenalectomy, still remains the treatment of choice for the general surgeon.

\section{Acknowledgments}

I wish to record my thanks to Prof. C. F. W. Illingworth, C.B.E., in whose department this work is being carried out, for his willing advice and interest. The method of pituitary destruction described here has been developed with the aid of university and hospital colleagues, and will be published in detail elsewhere.

\section{BIBLIOGRAPHY}

ARCHER, B. H. (1953), N.Y. St. F. Med., 53, 328.

ARNOLD, A. (1954), $\mathcal{F}$. clin. Endocr., 14, 859.

ATKINS, H. J. B., FALCONER, M. A., HAYWARD, J. L., and MACLEAN, K. S. (1957), Lancet, i, 489.

BAUER, K. H. (1956), Rev. suisse Med., 76, 320.

BAUER, K. H., KLAR, E., and SODER, E. (1956), Langs. Arch. u. Dtsch. Z. Chir., 281, 420.

BEATSON, G. I. (1896), Lancet, ii, 104, 162.

BISHOP, P. M. F., DE MOWBRAY, R. R., GLOVER, F. N., and THÓRNE, M. G. (1954), Larcet, ii, 1137.
BULBROOK, R. D., and GREENWOOD, F. C. (1957), Brit med. $\mathcal{F}$., $\mathrm{i}, 662$.

CADE, S. (1954), Ann. rov. Coll. Surg. Engl., 15, 71.

CADE, S. (1955), 33rd Annual Report British Empire Cancer Campaign, page 146.

CONNOLLY, R. C. (IG57), Discussion Roy. Soc. Med., March, 1957.

DAO, T. L. Y., and HUGGINS, C. (1955), A.M.A. Arch. Surg., $7 \mathrm{I}, 645$.

DAVIES, F. L. (1956), Lancet, i, 67I.

ELIEL, L. P. (1956), Symposium on Hypophysectomy, SloanKettering Institute. To be published.

EVANS, J. P. (1956), Symposium on Hypophysectomy, SloanKettering Institute. To be published.

FALLS, J. L. (1955), Cancer, 8, 143.

FERGUSSON, J. D. (1956), Discussion at Surgical Research Society, Glasgow.

FORREST, A. P. M., and PEEBLES BROWN, D. A. (1955), Lancet, i, ro54.

FORREST, A. P. M., PEEBLES BROWN, D. A., MORRIS, S., and ILLINGWORTH, C. F. W. (1956), Lancet, i, 399

GRAHAM, L. S. (1953), Cancer, 6, 149.

GREENING, W. P. (1956), Lancet, i, 728 .

GREENING, W. P. (1957), Discussion Roy. Soc. Med., March, I957.

HEWELL, W. E. ( r937), Amer. F. Cancer, 29, 659.

HUGGINS, C., and DAO; T. L. Y. (1 953), f.A.M.A., $151,1388$.

HUGGINS, C., and SCOTT, W. W. (1945), Ann. Surg., 122, 1031.

JAFFE, H. L. (1926), Amer. F. Physiol., 78, 453.

KARAKASCHEFF, K. J. (1906), Beitr. z. Path. Anat. u. z. allg. Path., 39, 373. (Cited by Falls, 1955.)

KELLY, K. H., FILDSTED, E. T., BROWN, R. F., ORTEGA, P., BIERMAN, H. R., LOWBEER, B. V. A., and SHIMKIN, M. B. (195I), Ұ. nat. Cancer Inst., II, 967.

KENNEDY, B. J. (1956), Amer. F. Med., 21, 721.

LAWRENCE, J. H., and TOBIAS, C. A. (1956), Cancer Res., 16, I85.

LAWRENCE, J. H., TOBIAS, C. A., BORN, J. L., and MCCOMBS, R. (1956), Conference on Endocrines and Cancer, Amer. Cancer Soc. Annual Scientific Session, New York.

Bibliography continued on page 394 


\section{BIBLIOGRAPHY}

ABRAHAMS, D. G., and WOOD, P. (195I), Brit. Heart F., 13, 519 BLOOMFIELD, R. A., LAUSON, H. D., COURNAND, A., BREED, E.'S., and RICHARDS, D. W., jun. (1946), $\mathcal{F}$. clin. Invest., 25, 639 .

BORST, J. G. G., and MOLHUYSEN, J. A. (1952), Lancet, ii, 304 FRIEDREICH, N. (1866), Dtsch. Arch. klin. Med., I, 241.

HALES, S. (1733) 'Statical Essays. Containing Haemastaticks: or, an account of some Hydraulic and Hydrostatical Experiments, made on the Blood and Blood-Vessels of Animals. W. Innys and R. Manby, London.

KEITH, A. (1 g08), $\dot{f}$. Anat. and Physiol., 42, I.

LAUBRY, CH., and PEZZI, C. (1913), Arch. Mal. Coeur, 6, 433.

LANCISI, G. M. (1728), 'De Motu Cordis et Aneurysmatibus,' Rome.

LEWIS, T. (1930), Brit. med. f., i, 849.
LEWIS, T. (1948), ' Diseases of the Heart,' Macmillan \& Co. Ltd., London, 4th Edition.

MACKENZIE, J. (1893), 7 . Path. Bact., 2, 84 and 273.

MACKENZIE, J. (I9O2), 'The Study of the Pulse,' Young J. Pentland, Edinburgh and London.

MORITZ, F., and VON TABORA, D. (1910), Dtsch. Arch. klin. Med., 98,475 .

MOUNSEY, J. P. D. (1955), Brit. Heart F., 17, 143.

POTAIN, P. C. E. (1867), Bul. Soc. Méd. Paris, 4,3

SZEKELY, P. (I94I), Amer. Heart F., 22, 360.

WIGGERS, C. J. (1928), "The Pressure Pulses in the Cardiovascular System,' Longmans Green \& Co., London.

WIGGERS, C. J.' (I949), 'Physiology in Health and Disease,' Henry Kimpton, London, 5 th Edition, p. 685

WOOD, P. (1950), Brit. Med. F., 2, 639 and 693.

WOOD, P. (I956), 'Diseases of the Heart and Circulation,' Eyre and Spottiswoode, London.

Bibliography continued from page 382: Surgical Endocrine Ablation for Advanced Breast Cancer

LUFT, R. (1957) Edinburgh University Lecture.

LUFT, R., and OLIVECRONA, H. (1953), $\mathcal{F}$. Neurosurg., 10, 301

LUFT, R., OLIVECRONA, H., and SJORGEN, B. (1952) Nord. med., $47,35 \mathrm{I}$.

LUFT, R., OLIVECRONA, H., IKKOS, D., NILSSON, L. B., and LJUNGGREN, H. (1956), Amer. F. Med., 21, 728

MALLARD, J. R., MCKINNELL, A., and FRANCOIS, P. E. (1956), Nature, 178, 1240.

MATSON, D. D. (I 956), Symposium on Hypophysectomy, SloanKettering Insitute. To be published.

MCKENZIE, A. (1955), Lancet, ii, I 129.

NATHANSÖ, I. R., RICE, C., and MEIGS, J. V. (1940), Amer. F. Obstet. Gynec., 40, 936 .

NICKSON, J. J. (I956), Symposium on Hypophysectomy, SloanKettering Institute. To be published.

NORTHFIELD, D. W. C. (1949), Proc. roy. Soc. Med., 42, 845.

NORTHFIELD, D. W. C. (1957), Discussion Roy. Soc. Med., March, 1957.

NOT'TER, G. (1957), Personal communication.

PATTISON, A. R. D., and SWAN, W. G. A. ( 1938 ), Lanct $t$, i, 1265.

PEARSON, O. H. (1956), Proceedings of the Fourth Conference in Steroid Hormones and Mammary Cancer, Council on Pharmacy and Chemistry, 1956.

PEARSON, O. H. RAY, B. S. WEST, C. D., HAROLD, C. C., MACLEAN, J. P., and LI, M. C. (I 954), 7. clir. Invest., 33, 956.

PEARSON, O. H, WEST, C. D., LI, M. C., MACLEAN, J. P., and TREVES, N. (1955a), A.M.A. Arch. Int. Med., 95, 357.

PEARSON, O. H. WEST, C. D., MACLEAN, J. P., LI, M. C., and LIPSETT, M. B. (1955b), Amer. Surgeon, 21, 1075.
PEARSON, O $\mathrm{H}$, RAY, B. S HAROLD C. C. LI, M. C., MACLEAN, J. P., and LIPSETT M. B. (r956), 买.A.M.A.,

PERLIA, I C. P., KOFMAN, S., NAGAMANI, D., and TAYLOR, S. G. (I956), Ann. Int. Med., 45, 989 .

RADLEY SMITH, E. I. (1957), Discussion Roy. Soc. Med.. I957. Surgical Forum, r952. Philadelphia, W. B. Saunders Co., 1953, p. $68 \mathrm{I}$.

RAY ${ }^{1953}$ B. P. (1956), Symposium on Hypophysectomy, SloanKettering Institute. To be published.

ROTH, M. (1889), Cor-Bl.f. schweitz. Aertze., 19, 146. (Cited by

Falls, 1955.)
ROTHENBERG, S. F., JAFFE, H. L., PUTNAM, T. J., and SIMKIN, B. (I955), A.M.A. Arch. Neurol. Psych., 73, 193

RUSSELL, D. S. (1956), Lancet. i, 466.

SHEEHAN, H. L., and SUMMERS, V. K (1949) Quart. F. Med.,

S'TRONG, 3.9 J. A , BROWN, J. B., BRUCE, J., DOUGLAS, M., KLOPPER, A. I., and LORAINE, J. A. (I956), Lancet, ii, 955 .

TAYLOR, S. G , LI, M. C., ECKLES, N., SLAUGHTER, D. P., and MCDONALD, J. H. (1953). Cancer, 6, 997

TREVES N (1956), Proceedings of the Fourth Conference in Steroid Hormones and Mammary Cancer, Council on Pharmacy and Chemistry, I056.

WEST, C. D., HOLLANDER, V. P., WHITMORE, W. F. RANDALI, H. T., and PEARSON, O. H. (I952), Cancer, 5,

YUHL E. T. HARPER, P. V., RASMUSSEN, T, and BERGENSTAL, D. M , Surgical Forum, r955, Chicago, W. B Saunders Co.. 1956, p. 489

References from page 388: Anticoagulants in Reconstructive Surgery

\section{REFERENCES}

I. DEGNI, M., and LANFRANCHI, W. (1954), Heparinizacao Regional: 'Vantagens o Desvantagens-Anais do Segundo Congresso Latino-Americano de Angiologia.

2. FREEMAN, L. E., WYLIE, E. J., and GILFILLAN, R. (I950), 'Regional Heparinization in Vascular Surgery,' Surg. Gynec. Obst., 90, 406, 412.

3. FREEMAN, N, E., and GILFILLAN, R. (1952), 'Regional Heparinization after Thromboendarterectomy in the Treatment of Obliterative Arterial Disease,' Surgery, 31, 1 I 5.
4. MURRAY, D. W., and BEST (1938), 'Use of Heparin in Thrombosis,' Ann. Surg., 108, $163,177$.

5. MURRAY, D. W., GORDON, and JAMES, J. M. (1940), 'Prevention of Acute Failure of Circulation Following Injuries to Large Arteries,' Brit. med. F., ii, 6, 7.

6. WYLIE, E. J., GARDNER, R., JOHANSEN, R:, and McCORKLE, $H$. (I950), 'An Experiment of Regional Heparinization,' Surgery, 28, 29, 35 .

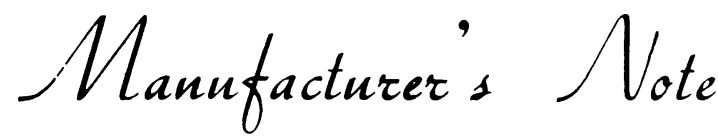

\section{SUMMER EXHIBITION}

\section{July II to August 23, 1957}

Although the Ilford Department of Radiography and Medical Photography is well known as a place of interest to the many visitors who enter its doors, this year a special effort is being made to add to its technical appeal by holding a summer exhibition.

The exhibition will include many attractive features embracing a wide range of radiographs of technical and diagnostic interest, practical demonstrations of some of the more unusual technical procedures and items of special photographic appeal.

Well-known members of the technical staff will be available for discussions and for the special demonstration features.

The exhibition, to be held at Tavistock House North, Tavistock Square, will be for all users of $\mathrm{X}$-ray and photographic materials and visitors can anticipate a cordial welcome. 